\title{
Transforming the Relations between State and Society in the Context of the 4th Industrial Revolution: Ukraine's Experience
}

\author{
Nina D. Chala \\ National University of Kyiv-Mohyla Academy, \\ ul. Skovorody 2, Kyiv, 04070 Ukraine \\ Oksana M. Poplavska \\ Kyiv National Economic University named after V. Hetman, \\ pr. Peremogy 54/1, Kyiv, 03057 Ukraine \\ cross' $^{\text {ref }}$ http://dx.doi.org/10.5755/j01.ppaa.19.1.25990
}

\begin{abstract}
The prerequisites and consequences of reformed relations between the state and society under the influence of the 4th industrial revolution and the requirements of sustainable development are reviewed in this article. The researchers offer to use the perception of governmental actions by society as a criterion to determine the role of the state in the conditions of digitalization. This allows identifying the features of various state aspects (monopolist, assistant and illusion). The authors identify the best tool which has acquired new social value in Ukraine, the dialogue. Having studied the features of public organizations, the authors structured the primary challenges and summarized the results (both positive and negative) of their activities in the context of digitalization. Special attention was paid to the adaptation of state administration to requirements of the 4th industrial revolution.
\end{abstract}

Keywords: dialogue, digitalization, sustainable development, matrix of state role determination, social values, public organizations.

Raktažodžiai: dialogas, skaitmenizavimas, darnus vystymasis, valstybès nustatymo matrica, socialinès vertybès, viešosios organizacijos.

JEL classification: $L 390 ; O 140$.

\section{Introduction}

Knowledge in the field of natural science has stimulated the progress of the 4th industrial revolution. This meant the development of digital economy, a change in the value orientations of society, a breakdown of traditional approaches to organizing labour hours and determining the balance between work and personal life, and the like. Its biological, ethical and environmental nature can also be attributed to the common features of the 4th industrial revolution because many developments are implemented in the field of environmental protection and aimed at people and their harmonious existence with nature. It is innovations that encourage business and governments to change the format of management and strategic goals. At the same time, the 4th industrial revolution created opportunities for greater involvement of the society in reaching these goals, on the one hand; yet, on the other hand, it revealed social and economic problems, such as the recession of trust toward the state, low ability of social partners to solve social and labour problems (instability of employment, the emergence of new non-traditional forms of employment, unstable income, unjustified income differentiation, and the like). 
Parallel to the processes of globalization (blurring of borders between countries by creating inter-state alliances or unions), changes in production relations, and combining the capacities of companies from different countries, opposite trends can be seen throughout the world. Such include the strengthening of national consciousness, the right of radical movements and insulation (France, Germany, Italy, etc., Brexit). On the one hand, governments forge cooperation and form a united security space; on the other, the national interests of particular countries become the bone of contention. In addition to this, we can see a gradual decline in economic growth in Europe over the past decade (C. Schuler, N. Hill, S. Marion, 2019), even despite the active implementation of the 4th industrial revolution's innovations. European countries are concerned about the low ability of EU member states to adapt to changes, as Jean-Claude Juncker emphasized. In order to keep the status of leading countries of the world, Europe should not resist innovations, but be in their forefront. (A stronger and more competitive EU industry: President Juncker opens 2019 EU Industry Days, 2019)

The authors working hypothesis is as follows: digitalization facilitates access to political life for all social groups; thus, the range of political participants has expanded. Unsophisticated words and slogans that people see in social networks seem to have credibility and are easily perceived. That is why they create the illusion of simple decision-making on a state level. Therefore, the relation between state and civil society takes new forms; other mechanisms and tools for conducting public dialogue and searching compromises arise. Thus, the impact of the 4th industrial revolution is manifested by increased requirements towards Ukrainian authorities regarding integrity, responsibility, transparency of government decision-making, social justice.

\section{Table 1. Modern understanding of the state's role}

\begin{tabular}{|c|c|}
\hline & \\
\hline $\begin{array}{l}\text { 'interactions between state institutions and societal groups. } \\
\text { They are focused on issues such as defining the mutual } \\
\text { rights and obligations of state and society, negotiating how } \\
\text { public resources should be allocated and establishing } \\
\text { different modes of representation and accountability' } \\
\text { (DFID, 2010, p. 15). }\end{array}$ & $\begin{array}{l}\text { society; drawn to the responsibility of citizens and public } \\
\text { authorities; the importance of representing various social } \\
\text { groups. The donor approaches are not related to the } \\
\text { current knowledge of the situation (it is crucial for the } \\
\text { modern Ukrainian state administration). }\end{array}$ \\
\hline $\begin{array}{l}\text { Government is in the last resort the en } \\
\text { men, of policemen etc. The es } \\
\text { government is the enforcement of its } \\
\text { and imprisoning. Those who are } \\
\text { government interference are asking } \\
\text { compulsion and less freedom. (Mises }\end{array}$ & $\begin{array}{l}\text { The boundary of state intervention into the regulation of } \\
\text { the economy: the state is encouraged to implement its } \\
\text { decisions through compulsion and punishment; a greater } \\
\text { level of state involvement means the limitation of } \\
\text { freedom. The drawback of this concept is the lack of } \\
\text { expense definition as an indicator of limiting state } \\
\text { involvement. }\end{array}$ \\
\hline $\begin{array}{l}\ldots . . \text { the state } \\
\text { will and was } \\
\text { means to ac } \\
13 \text { ) }\end{array}$ & $\begin{array}{l}\text { aximize } \\
\text { l powers } \\
\text { ciety (in }\end{array}$ \\
\hline $\begin{array}{l}\text { Without a stable and, to a certain degree, non-rent-seeking } \\
\text { states, modern production markets simply could not exist. } \\
\text { Everything would be destroyed. Entrepreneurs would not } \\
\text { be able to do business. In all developed industrial societies, } \\
\text { laws and regulations exist to protect not only } \\
\text { manufacturers but also consumers and employees (in } \\
\text { hazardous working conditions). (Fligstein N., 2013: p.38- } \\
\text { 39) }\end{array}$ & $\begin{array}{l}\text { The definition that the balancing of employers and } \\
\text { employees interests in an industrially developed society } \\
\text { was carried out by implementing rules that depended on } \\
\text { the attitude of the state. Economic growth depends on the } \\
\text { situation within the state, on institutions and social } \\
\text { technologies that create businesses, shape class struggle } \\
\text { and regulate competition between businesses. }\end{array}$ \\
\hline
\end{tabular}




\section{From guarantor to partner: changing the role of the state}

Organizing humanity in the form of a state is a great achievement, which demonstrates the ability to solve problems and coordinate the interests of groups of people living on a certain common territory. Fligstein proves that as a social structure, market and state cannot exist separately; the state allows the market to exist (Fligstein N., 2013: p. 24), and the market is a necessary feature of each state. At the same time, a review of the history of developing different states proves that the change in the form of market relations influenced the changes in the state structure. If the influence on the market became more rigid and authoritarian, the country suffered a collapse, as, for example, the Roman Empire (Greber D., 2015. p.102); but since its democracy was weak and the government gradually became authoritarian, the Empire began to lose its territory and subsequently split into smaller states (Spengler, 2009).

The modern understanding of the state's role is transformed in the context of globalization, the formation of corporate government style, the promotion of democracy and, at the same time, a profound crisis of income (the inequality between the income of people in different countries is increasing (Stiglitz J, 2015). Today, most authors tend to praise the role of the state (Table 1), but the destruction of the social welfare state model is apparent. Moreover, given the challenges of the 4th industrial revolution, such an unstable position is harmful. Governments that do not have specific state development plans that ensure sustainable development are doomed to failure.

That is why discussions about the state's role in managing the market and society are regularly held in the scientific community. For their study, the authors used the perception of governmental actions by society as a criterion (i.e., how much the society is willing and able to delegate its rights to governments and expect appropriate security and can allow limitations of its own freedoms and rights) and generated a matrix for defining the state's role (see Table 2).

Table 2. The peculiarities of cooperation in the process of the innovation creation

\begin{tabular}{|c|c|c|c|c|c|}
\hline \multirow{2}{*}{\multicolumn{2}{|c|}{ CRITERIA }} & \multicolumn{4}{|c|}{ Limitation of rights and freedoms } \\
\hline & & absent & partial & segmental & total \\
\hline \multirow{3}{*}{$\begin{array}{l}\text { Delegation and } \\
\text { execution of } \\
\text { rights }\end{array}$} & full & & & \multicolumn{2}{|c|}{$\begin{array}{l}\text { authoritarianism, strong hierarchy - monopolist } \\
\text { state }\end{array}$} \\
\hline & partial & & \multicolumn{2}{|c|}{ social state - assistant } & \\
\hline & absent & \multicolumn{2}{|c|}{$\begin{array}{c}\text { anarchy, collapse - illusion } \\
\text { state }\end{array}$} & & \\
\hline
\end{tabular}

Source: Authors

Notably, the restriction of rights and freedoms may be completely absent when there are no clear laws and regulations, or they are not complied within the context of total corruption; partially absent - when certain rights are restricted, such as the freedom of the press, communication or property (a result of political prejudice or religious restrictions); segmentally absent - when the state undertakes the right to determine the strategy and general vector of the society's development by limiting the rights (in relation to business, environmental responsibility) within the law; or totally absent - when the state fully undertakes the right to determine what complies with the law and what violates it; when there is no free market and freedom of speech. Delegation of rights to the state and their execution are grouped depending on the completeness of implementation: full, partial, none.

The authors identified three main roles of the state: monopolist, assistant and illusion. In this classification, the monopolist does not provide communication with public organizations. The society has no opportunity to influence the policy of the state; the assistant is the guarantor of the rights and freedoms of all market actors, it has a balanced system of social guarantees and benefits provided by a favourable climate for business development; in the illusion state, the government is unable to execute its obligations, cannot influence the economy, the society is unbalanced and does not trust state institutions; as a rule, corruption schemes are typical in such a government. According to this classification, Ukraine belongs to the third group. This group also includes most of the countries of 
Central Asia, North America and Africa. The group of assistant states includes Western Europe, USA, Canada, Australia, Israel, etc. The monopolist state (in its classic manifestation) cannot be identified in the current climate due to digitalization (hyperactivity in social networks), and, as a consequence, the increased activity of society in the life of the state.

\section{The readiness of the Ukrainian society to change the paradigm of state administration}

The Ukrainian civil society has repeatedly proved its maturity and readiness to influence state authorities drastically. At the same time, the question of the society's readiness to build effective communication and feedback with the state, take responsibility and play an active role in paying its public duties, and minimize layoffs and limitations of social services remain unsolved. A study of the Ukrainian society has demonstrated a different level of flexibility and willingness to change. So, the population and civil society are open to changes (position 64 out of 136); the business sector shows a lower level of willingness (position 89 out of 136); and the state shows a complete unwillingness to change (position 126 out of 136) (KPMG, 2017). At the same time, position No. 64 indicates a rather moderate conservative behaviour. The attitude of the business sector is alarming, as this position is also an indicator of innovations in business. The state authorities at position 126 indicate a stable unwillingness to change. A significant gap between the readiness of the population and the business sector to change indicates the pressure of Ukrainian society on the state in order to implement changes. However, position 64 indicates that the population is not ready to change its behaviour yet.

The Constitution of Ukraine (Constitution of Ukraine, 1996: Art. 38-40) provides for mechanisms of influence by the civil society on the adoption of state decisions utilizing a referendum, elections, and sending appeals. The introduction of electronic petitions and a public budget, in its essence, guarantees the implementation of these mechanisms at a new level of technical development, which facilitated the participation of citizens not only in decision-making at a state level but also in the initiation of urgent problems consideration. The introduction of these mechanisms has not eased the polarization of Ukrainian society. Regarding the vector of foreign policy, 53\% of the population supports EU-integration (KIIS, 2017); yet, NATO membership as a guarantee of security is supported only by $45 \%$.

In the Ukrainian society, the most sensitive topic concerns the reduction of social benefits guaranteed by the state, in particular medical services, financing of education and culture, and the like. According to the author's research, the complex of benefits guaranteed by the state and associated with social orientation is consistent with world practice. For example, the right to work was first provided in the Constitution of Mexico in 1917; in Europe, in the Weimar Constitution of Germany in 1919; in Ukraine, this right is provided by Art. 43 of the Fundamental Law of Ukraine. Basically, the right to work acquired legal form in the UN Universal Declaration of Human Rights (Article 23) in 1966 (UN General Assembly, 1948). The social goals of the country are also implemented through the state guarantees on the preservation of health, education, equality of rights and the like. These guarantees fully come across with the values of each citizen and society as a whole. At the same time, a mutual system of values does not guarantee a common vision of enforcement mechanisms and the provision of rights. The question arises: how should guarantees be provided? The first and the already tested mechanism is the statutory regulation in a particular sphere and the state intervention into relevant processes. In such a mechanism, the state "takes over" the obligation to provide rights to people. However, in terms of a crisis, the resource capacity of the state is limited; thus, the level and quality of guarantees implementation suffer.

Until recently, the declared social goals in Ukraine were implemented by guaranteeing them (that is, by the state intervention into the sphere of education and health care) and providing other human rights. Considering the reduction of expenses on these purposes, the level of society's satisfaction with the quality of such services is constantly decreasing, which is reflected in confidence ratings. For example, according to a survey conducted by the sociological group "Rating" in JulyAugust 2017, $47 \%$ of respondents noted that the overall quality of public health services in the country has changed for the worse over the past two years; a third (34\%) believe that nothing has 
changed at all (Sociological group RATING, 2017); that is why the population rarely turns to doctors. The survey results show an increase in the number of people who claim that treatment is very expensive for them and their families (even among those who have health insurance): from 39\% in October 2016 to $61 \%$ in 2017 (Sociological group RATING, 2017). This discrepancy between data from different sources and the actual rating by citizens leads to distrust of state institutions and initiatives.

At the same time, the level of trust towards public organizations is growing; in particular, according to a study conducted by the Kyiv International Institute of Sociology, more than $50 \%$ of Ukrainians trust volunteers and public organizations. The most trusted among Ukrainians are ordinary people who live nearby (68\%), volunteers who help the army and migrants (63\% and $61 \%)$, the church $(51 \%)$, and the Armed Forces of Ukraine (51\%); the least trusted is the government of Ukraine (11\%), the Verkhovna Rada of Ukraine (8\%) and the Russian media (4\%) (KIIS, 2018). Thus, we determine that Ukraine is at the parting of the ways: either to preserve the state's role as a guarantor or to search for other forms of interaction with the civil society. Ukrainian citizens show a moderate willingness to change their behaviour; therefore, radical changes in the mechanisms of state administration are not relevant at the moment. Thus, due to loss of trust, state institutions should change and establish effective communication under the pressure of society.

\section{Evolution of management systems in Ukraine in terms of the 4th industrial revolution}

As already noted, technological innovation promotes social inclusion, thereby improving the quality of life and expanding opportunities for everyone, regardless of physical abilities. At the same time, it is a certain type of test for the government, business and citizens on the ability to take advantage of the progress and quickly respond to the challenges that arise. (Chala N., Poplavskaya O., 2018). In terms of state administration, the modern hierarchy has many errors; thus, the so-called "horizontal" management system appears. In turn, it is a by-product of a developing civil society, strengthening of each citizen's social responsibility.

Until the twentieth century, the state mainly had a hierarchical system of government; this allowed to solve the operating objectives of sovereignty and socio-economic development effectively. During the existence of the Eastern Bloc, especially in countries of the former USSR, the society entirely relied on the state when implementing their rights: labour, residence, medical care, education, etc. In conditions of limited and inaccessible information, it seemed the most acceptable form of interaction (it was, in fact, guardianship) between state and society. Consequently, the initiative of citizens was at a low level, which subsequently began to slow down the innovative development of the country itself and increased people's dissatisfaction with life. From the perspective of the market economy at that time, the state was always forced to seek compromises with public organizations, mainly professional. Therefore, during the twentieth century, Europe has built a good background of social partnership.

Digitalization creates a "window of opportunity" for the state: availability of information, its volume is increasing, the speed of data updates is also growing; at the same time, there are risks of cyber-attacks and external intrusion into automated management processes. Globalization also imposes several restrictions (dependence on the value orientations of the investor, his goals, and interests) and provides advantages (the synergetic effect of implementing corporate programs). Despite narrowing the field of action of trade unions, the experience of social dialogue remains an important component of the interaction between business, state and employees.

The state's social security obligations remain equally important. Considering ILO's recommendations, Ukraine has chosen the path to a two-dimensional strategy for expanding social security. It is clear that this strategy involves the development of horizontal and vertical dimensions. The horizontal dimension of the social security expanding strategy (according to ILO's methodology) provides for the rapid introduction of minimum levels of social protection, which contain basic guarantees in the field of social security. Consequently, they create conditions for all those who need to have access to indispensable types of health services and receive a guaranteed income, at least at 
the minimum level established by the state (ILO, 2013: p.5). The vertical one provides for the involvement of public organizations, society, and business in the implementation of all programs. This whole system cannot be fully implemented employing a hierarchical management system; it is important to form a horizontal, two-dimensional system. It operates with large volumes of data, is time-consuming in case of traditional data analysis, updates, and the like.

In terms of the 4th industrial revolution, the government's ability to operate large databases has expanded significantly. Furthermore, the first thing that was introduced in Ukraine is document automation and electronic digital signatures. However, the transition to document automation has not been carried out simultaneously; so far, some regional and district administrations have not implemented an electronic document automation system yet. In addition, high competition on the market has contributed to the fact that different agencies can choose a custom design program. Public and private companies have also implemented document automation systems on different platforms. For example, the Joint Stock Company «Ukrainian Railway» (JSC «Ukrzaliznytsia») operates the LOTUS system. The FossDoc document automation system operates in some commercial banks and state institutions of Ukraine (Foreign Intelligence Service of Ukraine, Sumy regional state administrations) (FOSS On Line, 2019). Therefore, a situation arises when document automation is implemented inside the organization; yet, interdepartmental communication and contacts with external market agents is realized in paper form.

The opportunities offered by the Industry 4.0 have contributed to a revival of society's participation in legislation. In particular, the "Electronic petitions" portal was introduced in Ukraine. The purpose of this portal is to submit proposals to the public with their subsequent approval by the President of Ukraine and the Cabinet of Ministers of Ukraine. However, almost 30 thousand petitions were registered on the portal during the first two years of its implementation; among these, only 40 collected the number of votes necessary for consideration ( 25 thousand). In other words, there is no cohesion between people regarding management decisions; one of the reasons is the low effectiveness of the project (the society does not see specific actions and results). An important step towards strengthening cooperation between society and local administrations is the introduction of Internet platforms for allocating local budgets. Such platforms have been created in Kyiv, Lviv, Kryvyi Rih. For example, out of 38 projects submitted in 2018 in Lviv, 30 were implemented; 309 projects were submitted in Kyiv the same year; among them $70 \%$ received support, and 115 projects have already been implemented.

Industry 4.0 is also manifested in the organization of labour of most personnel (both in governmental, non-governmental and public organizations). According to the State Statistics Service of Ukraine, 40237 enterprises used computers in 2017 (which is $12 \%$ of all enterprises in the country); 24888 enterprises had a local computer network, and 26984 enterprises had Intranet. At the same time, statistics show that cloud technologies were bought by only 4135 Ukrainian enterprises in 2017 (just over $1 \%$ in the country); cloud technologies were used mainly in e-mails, financial and accounting applications (most enterprises bought cloud computing), as well as office software, database hosting, file storage services, etc. (State Statistics Service, 2018). Meaning to say, it is too early to talk about a breakthrough in the introduction of modern IT technologies in the current Ukrainian climate.

\section{Modern challenges of public organizations}

After researched the participation of public organizations in social problems, the authors concluded that the main objectives could be classified as follows:

- Informational, whose task is to deliver information about the problem areas in the economy, society, etc. to government and business;

- Entrepreneurial, whose task is to stimulate social entrepreneurship;

- Fund-raising and volunteer, whose purpose is to provide financial and moral assistance to people in trouble, affected by deception or violence; 
- Educational, aiming to popularize science, to execute educational projects, to train ordinary citizens of financial literacy, etc.

Having analyzed the content of websites and personal pages in social networks on the activity of public organizations, we have identified the following trends:

- most organizations cooperate both with each other and with business partners (more than 1/3), joining forces to achieve their goals (for example, the Analytical Center for the Development of Society, the Association of open cities);

- projects relevant to Ukraine are developing more rapidly (problems of Donbas integration, palliative medicine, education, environmental protection);

- the vast majority of public organizations prefer to communicate through Facebook; yet, organizations that have a broad experience of working in Ukraine, are more active and influential, have an extensive network of branches and partners mainly cooperate through websites;

- a small part of public organizations is declared but does not have any electronic contacts (for instance, the "NGO "Institute for research and development" has a website, but it does not work; information about the activity of the organization is confidential).

Having analyzed almost 80 articles posted by public organizations on the content and their principal messages, the authors have identified the following challenging areas of public organizations:

- forming the team of the organization (under-qualified personnel and insufficient knowledge about the correct arrangement of activities);

- a narrowed market of Ukrainian companies ready to be engaged in charitable activities and to support public organizations projects;

- inability to attract investors, prove the effectiveness of social projects, a vague understanding of the essence of the projects;

- the lack of reliable public information on the implementation of social projects for all groups of society (there is practically no information about the activities of numerous public organizations in Ukrainian media; it is only known to a small interest group);

- the "market" of public organizations is dependent on state support (as a rule, organizations in partnership with the government operate more successfully);

- citizens often do not know about the existence and activities of public organizations in their region.

The gradual distrust of citizens in the possibility of change for the better in their own country is also a negative factor; namely, the society's activity is decreasing in comparison with 2014. So, in $2018,66.9 \%$ of respondents said that their attitude to the government has changed for the worse. Additionally, 59.8\% believe that the attitude of the government towards them has changed for the worst. In general, most of Ukrainians expectations have not been met (Razumkov Center, 2019). Therefore, there is a gradual decrease in the participation of citizens in social projects.

Very often, social projects are implemented by public organizations at no charge, and their members are involved outside office hours. The most active participants are young people. For instance, the public project "City of professions", held in Kyiv in 2017, was organized by studentsvolunteers from various higher educational institutions who worked with children on different platforms. They demonstrated the peculiarities of various professions, providing an opportunity to perform simple assignments in each field. As a rule, students organize concerts and celebrations of significant events at universities. At the same time, a survey conducted among students showed that the motives for participation in extracurricular activities (for example, career guidance of pupils, participation in the theatre group at the university) are getting additional bonuses in the form of raised status in the team and increasing the rating or natural disposition to such activities. However, in the case when a student is employed, his social activity is significantly lower, because it is challenging to combine study and work. Thus, another real challenge for public organizations is the lack of time; an extensive workload of the socially active population in other areas (work, professional 
development, etc.) reduces the number of participants and the level of activity in public life, cooperation with government agencies, etc.

\section{Examples of creating social value through interaction between state and society}

Today, the vector of development is aimed at involving society and business into solving social problems. This requires high responsibility from each market actor and person because the government becomes a partner, not only a moderator of the socio-economic life in the country. Such changes are impossible without the transformation of notions, values and motives of market actors, and their view of life. If a person is considered a value carrier, the model of the modern Ukrainian citizen contains several specific (not inherent in the previous stages of development) components. In particular, the significance of personal growth values (especially among the youth), the flexibility of working time, career, status and social responsibility has increased. The value of freedom was actualized (not permissiveness, but a conscious, responsible attitude to life, a tolerant perception of the diversity of its manifestations). There is a new value in the Ukrainian society - the dialogue (interaction) between the state and public organizations, communities. The new value is the chance for Ukraine to restructure its socio-labour and economic relations as quickly as possible; this is a way to reach the Sustainable Development Goals. It is essential for countries with similar socio-labour and economic indicators to understand the experience of Ukraine:

- The 4th industrial revolution provided tools for better communication, which helped society to form an interest in the projects and accomplishments of the government;

- The interests of the state are discussed and evaluated for compliance with the existing social values;

- The state, which has not yet fully realized its role in the socio-economic life, tries to pressure public opinion; still, it takes the recommendations of authoritative public organizations into account;

- Society becomes more responsible for its future, but the risks of promoting only national interests still remain (the European values of the open market are not taken into account);

- Communities are actively involved in the formation of their local budgets, determining the priorities of their development;

- The society's involvement is limited by the level of IT knowledge and the availability of resources (gadgets, information sources, etc.);

- Brand risks increase because most users cannot or do not want to check the accuracy of information (they choose specific sources and do not trust others); besides, there is no protection against unfair competition (through social networks);

- Media literacy of government leaders allows increasing the level of confidence in the state (this phenomenon, in particular, resulted in the election of Zelensky as President of Ukraine).

Thus, the interaction of state and society requires the standardization and regulation of basic rules when distributing the limits of interference in the interests of each party or making joint decisions and taking over responsibility. Additionally, it is crucial to ensure transparency and scientific accuracy of government decisions on proposals and community projects.

\section{Conclusions}

1. Once again, science proves to be the driving force of change both in the economic and social life of state and society. It motivates to reconsider the existing relations, to search for the best mechanisms to coordinate the interests of various market actors. Today, IT technologies account for the emergence of a new state model, where society (public organizations) has become an active participant in the processes of decision-making (it is no longer just a consumer and critic of state policy). On the one hand, this model looks unbalanced with high risks of entropy. On the other hand, it has significant adaptive capabilities. The newly emerged social value - the dialogue between state and society - allows for balancing the interests of various market actors until they are harmonious. 
2. Our study confirmed the working hypothesis about the unstable tendency to form a value model for Ukrainian citizens, in which the value of personal responsibility for the future is fundamental; where the government is perceived as a body to implement the needs delegated to it by the society, and the society is the initiator and inspector of changes. The new value has arisen - the interaction of the state with both society and business. If the credibility of public organizations increases, the named value model will take a more definite shape. Considering this, the authors forecast the establishment of a horizontal management model in Ukraine in the next ten years.

3. Research on the impact of Industry 4.0 on the transformation of relations between states societies need to deepen; this should be done to identify dominant social and economic behaviour patterns of citizens in the context of digitalization and to design an effective model of socio-economic development in the country by identifying the roles and noting the responsibility centres for each participant. The appearance of non-system leaders (like V. Zelensky in Ukraine) and the use of new influence methods on public opinion (TV series "Servant of the People") most likely indicate ignorance of global megatrends, rather than an irrational behaviour of the civil society.

\section{References}

1. A stronger and more competitive EU industry: President Juncker opens 2019 EU Industry Days. Published on: 01/02/2019. Available on the Internet: https://ec.europa.eu/growth/content/stronger-en

2. Schuler C., Hill N., Marion S. (2019). Banks-Europe. 2019 Outlook. 12.12.2018 p.9-10

3. Chala N., Poplavskaya O. (2018). Social Responsibility of Business: The Chalenges of the 4-th Industrial Revolution. Corporate social responsibility - Zielona Góra, Poland, 2018, p. 54-71

4. Constitution of Ukraine. (1996). Available on the Internet: https://zakon.rada.gov.ua/laws

5. DFID (2010). Building Peaceful States and Societies: A DFID Practice Paper. UK. Department for International Development. Available on the Internet: http://www.gsdrc.org/docs/open/con75.pdf

6. Fligstein N. (2013). The Architecture of Market: An Economic Sociology of 21st Century Capitalist Societies. M .: Higher School of Economics, 2013, 392p.

7. Greber D. Debt. The first 5000 years of history. M .: Admarginmb 2015, 528p.

8. Herald. Officially about taxes (2013). Letter - Clarification. Concerning the implementation of NGO of entrepreneurial activity. Available on the Internet: http://www.visnuk.com.ua/ua/pubs/id/8724

9. ILO. (2013). Strategy of the International Labor Organization. Social security for all: building up minimum levels of social protection and comprehensive social security systems: a summary statement /International Labor Organization, Bureau for Central and Eastern Europe.: $2013-77 \mathrm{p}$.

10. KIIS. (2018) Trust in Social Institutions, December 2018. Available on the Internet: https://www.kiis.com.ua/?lang=ukr\&cat=reports $\& \mathrm{id}=817 \&$ page $=1 \& \mathrm{t}=1$

11. KPMG (2014). Future State 2030: Global MegaTendings that Affect Governments. Available on the Internet: https://assets.kpmg/content/dam/kpmg/pdf/2014/09/Future_State_2030_UA_v3.pdf

12. Sweeney P. (2018). The Collapse Of European Social Democracy, Part 1 on 8th October 2018 Available on the Internet: https://www.socialeurope.eu/the-collapse-of-european-socialdemoc

13. State Statistics Serviceof Ukraine (2018). Use of information and communication technologies at enterprises for 2017. Available on the Internet: http://www.ukrstat.gov.ua/

14. Stiglitz J. The Price of Inequality: How Today's Divided Society Endangers Our Future. 2015, 512p. 
15. Ukrainian Institute of Strategies for Global Development and Adaptation. (2019). Conflict in Donbass. Available on the Internet: https://uisgda.com/ua/konflikt_v_donbasse.html

16. UN General Assembly (1948). Universal Declaration of Human Rights. PES/217 A Available on the Internet: https://www.irs.in.ua/index.php?option=com_content\&view=article\&id=82:1\&catid

17. Verkhovna Rada of Ukraine (2014). Agreement on Association between Ukraine, on the one hand, and the European Union, the European Atomic Energy Community and their Member States, on the other hand. Available on the Internet: https://zakon.rada.gov.ua/laws/show/984_011

18. Verkhovna Rada of Ukraine. (2010). Law of Ukraine No. 2862-VI of 23.10.2010 "On Social Dialogue in Ukraine" Available on the Internet: https://zakon.rada.gov.ua/laws/show/286217

Nina D. Chala \& Oksana M. Poplavska

\section{Valstybės ir visuomenės santykių keitimas 4-osios pramonės revoliucijos kontekste: Ukrainos patirtis}

Anotacija

Straipsnyje apžvelgiamos reformuotos valstybės ir visuomenės santykių, paveiktų 4-osios pramonès revoliucijos, prielaidos ir padariniai bei darnaus vystymosi reikalavimai. Tyrejai siūlo naudoti visuomenès suvokimą apie vyriausybès veiksmus kaip kriterijų, siekiant nustatyti valstybės vaidmenį skaitmenizacijos sąlygomis. Tai leidžia nustatyti ịvairių valstybės aspektų (monopolisto, padejjejo ir iliuzijos) bruožus. Autoriai išskiria geriausią ịrankį, igavusị naują socialinę vertę Ukrainoje, dialogą. Ištyrę visuomeninių organizacijų ypatumus, autoriai susistemino pagrindinius iššūkius ir apibendrino savo veiklos rezultatus (ir teigiamus, ir neigiamus) skaitmenizacijos kontekste. Ypatingas dėmesys buvo skiriamas valstybinio valdymo pritaikymui 4-osios pramonès revoliucijos reikalavimams.

Chala Nina D. - mokslų daktarè viešojo administravimo ir ekonominès politikos srityse, profesorè, vadybos ir biznio valdymo katedra, Ekonomikos fakultetas, Nacionalinio universiteto KijevoMohylos Akademija, Ukraina.

email: n.chala@ukma.edu.ua

Poplavska Oksana M. - PhD (ekonomikos srityje), Kijevo nacionalinis ekonomikos universitetas, pavadintas V. Hetmano, Personalo vadybos ir darbo ekonomikos katedra, Personalo vadybos, sociologijos ir psichologijos fakultetas, Ukraina.

email: oksanadom@ukr.net

Chala Nina D. - Doctor of Science (Public Administration, Economic Policy), Professor, Departmens of Marketing and Business Management, Faculty of Economics, National University of Kyiv-Mohyla Academy, Ukraine.

email: n.chala@ukma.edu.ua

Poplavska Oksana M. - PhD (Economics) Personnel Management and Labor Economics Department, Faculty of Personnel Management, Sociology and Psychology, Kyiv National Economic University named after V. Hetman, Ukraine.

email: oksanadom@ukr.net 